\title{
The effect of formalization in the enterprise
}

\author{
Zuzana Skorková1,** \\ ${ }^{1}$ University of Economics in Bratislava, Faculty of Business Management, Department of \\ Management, Dolnozemská cesta 1, Bratislava, Slovakia
}

\begin{abstract}
Formalization is one of the pillars of a bureaucratic company. It is manifested by a high number of formally given rules, procedures and written guidelines. These documents guide the way of employees' conducting and their activities. Precisely defined rules determine the way of work and based on rules the activities are divided among the employees of the company. They feel that the rules are readable, clear and valid for everyone. Research shows a positive correlation between the effectiveness of business activities and the degree of formalization. On the other hand too detailed rules prevent creativity, initiative and selfdevelopment. Employees require rules and written materials from the sovereign' supervisor to solve every problem, often one that the employees themselves can easily solve. Our contribution is dedicated to formalization and its impact on employee initiative to make changes in the organization. In a sample of 190 companies, we confirmed that with the increasing formalization, the initiative of employees to change has been decreasing.
\end{abstract}

\section{Introduction}

Formalization is represented by the rules, regulations, procedures and other written documents that organizations create to support and coordinate different and challenging tasks through behavioural regulation. The more tools to streamline the activity and the more definitions, descriptions and internal procedures the organization uses, the higher the level of formalization. A high level of formalization is typical for a bureaucratic enterprise. The opposite of this is that management trusts employees - their knowledge, skills and judgment - and does not insist on such a high degree of formalization. [1]

Different theorists characterize formalization in different ways. Weber [2] himself defined it as a way of regulating activities in an organization through formal rules. In Weber's concept of bureaucracy, there is real authority in regulations. The power of superiors is precisely defined by regulations. But Organ and Green [3] say that formalization is a way of controlling individual activities through rules and procedures.

\footnotetext{
*Corresponding author: zuzana.skorkova@euba.sk
} 
Mintzberg [4] claims that organizations formalize employee behaviour in order to limit their variability and thus better anticipate and control it. According to him, formalization serves for easier coordination of activities. However, it also gives other reasons for formalization. These include the need for keeping the things in order. According to Mintzberg [4] highly formalized structures are above all neat and "warm the hearts of people who like to see things organized". The definition by Armandi - Mills [5] is very different, as they say that formalization is a degree of standardization of individual tasks in an enterprise.

Given the formal and informal part of the organization, we can assume two absolutely extreme cases. There are companies with a high degree of formalization that are very austere and inflexible. In highly formalized companies, there is a well-defined written procedure for almost every work activity that determines what and how to be implemented and who is responsible for what and to what extent. Especially bureaucratic companies are characterized by a high degree of formalization. However, the organizations without any formalization are also known as their counterpart. We define these as informal and very volatile, where there are no officially established rules or procedures. Formalization leads to system stability, simplifies coordination and control. Employees know exactly what to do and how to do it. From a management perspective, it is certainly easier to manage a highly formalized system than an organization without any official rules.

But organizations are based on natural human communication, which is not always formal. Formalization within an organization creates a framework and boundaries that determine the system's ability to maintain its internal order. However, too high a degree of formalization can hinder the development of employee initiative and critical thinking, which is often criticized for bureaucracy. [6-8] Formalization is measured simply by counting the pages of the documentation governing the relationships between employees or working procedures, instructions, rules within the enterprise. It can be stated that the larger enterprises are the more formalized they are. Large enterprises tend to be highly formalized because they have dozens of written rules determining the required behavior and actions of employees. On the other hand, a small, family-run business may have almost no written rules and will be considered informal, yet it can work without problems and very successfully. Nowadays, it is a great challenge for managers to determine the optimum degree of formalization that would ensure order and stability while avoiding cumbersome. As Sedlák [9] argues, non-essential, special or individual things need to be left to the initiative of its members, as a large number of regulations restrict human beings, reduce or eliminate the initiative of lower organizational units and hinder the reasonable use of all human abilities. The author also adds that a pre-formalized organization is becoming cumbersome. Therefore, the formal basis of the organization should be limited to an appropriate level, which means knowingly leaving the possibility of informal relationships and activities to emerge.

The degree of organization is closely related to formalization. The degree of organization expresses the relationship between what is already organized in the form of rules and what is dealt with spontaneously in the immediate context of the implementation of a specific activity. If the organization has a degree of organization too low, the manager often has to deal with tasks of an operational nature. Of course, this takes him time to devote to conceptual issues. The opposite of low organization is too high organization, where there are many rules in the company that are extremely detailed - which is typical of bureaucracy. It can be very time consuming to create such a rule structure. In addition, the organization is gradually becoming an overly rigid apparatus [10], which is only concerned with compliance and is unable to respond flexibly to changing conditions. This is also evidenced by research by Hofstede - Hofstede (2006) [11], where a strong negative correlation between business formalization and results orientation has been demonstrated. 
Therefore, in their study they conclude that high formalization leads to a more processoriented than result-oriented approach.

The main purpose of in-house standards is to determine a uniform and binding structure of rules of different nature according to the needs of the business. As Sedlák [9] says, organizational standards used in one organization form their system, which is hierarchically arranged. It is a purposefully arranged set of groups of organizational standards that consist of individual organizational standards. The system of organizational standards of organizations can be divided mainly from the hierarchical point of view, according to organizational levels (company, plant, etc.) and from the generic point of view.

Standards in organizations can form a comprehensive code, respectively. system of organizational standards. These organizational standards vary in scope, commitment (for all or for a specific group), validity, scope (affects all or part of a company) and diction (binding or informative. The formulation of sentences is also important, which should reflect the word order of the type: "Who - where - when - with whom - why and why." [12]

Formalization is one of the basic manifestations of bureaucracy in a company. Its advantages and disadvantages are summarized in the following table.

Table 1. Advantages and disadvantages of formalization.

\begin{tabular}{|c|c|}
\hline Advantages of formalization & Disadvantages of formalization \\
\hline $\begin{array}{l}\text { Precisely defined rules determine the way work } \\
\text { and activity are divided among the employees of } \\
\text { the company. They feel that the rules are } \\
\text { readable, clear and valid for everyone. }\end{array}$ & $\begin{array}{l}\text { Too detailed rules prevent creativity, initiative } \\
\text { and self-development. Employees require rules } \\
\text { and written documentation from their supervisor } \\
\text { to solve any problem (even one that they can } \\
\text { solve themselves). }\end{array}$ \\
\hline $\begin{array}{l}\text { The scope of work is predetermined by formal } \\
\text { rules, which is understandable for employees. }\end{array}$ & $\begin{array}{l}\text { Clinging to old, established and often inefficient } \\
\text { ways of doing business, since only these are } \\
\text { accurately captured in procedures. }\end{array}$ \\
\hline $\begin{array}{l}\text { The formal rules cover all areas of life - from } \\
\text { wage conditions to disciplinary rules. They lead } \\
\text { to order, harmony, readability. }\end{array}$ & $\begin{array}{l}\text { The process itself is more important to many } \\
\text { employees as a result of the activity. [11] Many } \\
\text { employees do not know the business strategy or } \\
\text { added value that their product / service } \\
\text { represents to the client. They are only fixed to } \\
\text { the correct execution of the process and under all } \\
\text { circumstances. Deviation from the result. }\end{array}$ \\
\hline $\begin{array}{l}\text { Research shows a positive correlation between } \\
\text { the effectiveness of business activities and the } \\
\text { degree of formalization. [13] }\end{array}$ & $\begin{array}{l}\text { Employees do not want to take responsibility [8] } \\
\text { and do not feel autonomous. Juillerat [14] } \\
\text { confirmed the negative correlation between the } \\
\text { degree of formalization and the autonomy of } \\
\text { employees. }\end{array}$ \\
\hline $\begin{array}{l}\text { Standards promote a culture of continuous } \\
\text { improvement throughout the value chain. } \\
\text { The use of standards helps to identify and } \\
\text { minimize risks, simplifying control. }\end{array}$ & $\begin{array}{l}\text { Standards require regular revision. Practice often } \\
\text { proves the existence of conflicting regulations. }\end{array}$ \\
\hline $\begin{array}{l}\text { Rules are the standards by which it is possible to } \\
\text { continuously measure and improve the quality of } \\
\text { services. Formal performance appraisal and a } \\
\text { formal R\&D function contributed positively for } \\
\text { the performance of only established firms. [15] } \\
\text { Formalization of performance appraisal has a } \\
\text { positive effect on change in trust in leadership. } \\
\text { [16] }\end{array}$ & $\begin{array}{l}\text { Too many formal rules make the system unclear. } \\
\text { It gives power to those who know the rules and } \\
\text { often abuse their knowledge against those who } \\
\text { do not master the formal rules. }\end{array}$ \\
\hline
\end{tabular}

Source: Own processing. 


\section{Methods}

Our contribution is dedicated to formalization and its impact on employee initiative to make changes in the organization. In a sample of 190 companies, we confirmed that with the increasing formalization, the initiative of employees to change has been decreasing. The statistical sample ( $\mathrm{N}=190$ respondents) is comprised of managers from enterprises running their business in the Slovak Republic. We conducted the research through a questionnaire data collection during the last 2 months of 2019. The data obtained through the questionnaire method present a nominal and ordinal variables. The data were analysed in PSPP statistical software. Hypotheses were tested at a significance level of $p \leq 0.05$.

\section{Results}

In our study, we were focused on the manifestations of formalization in the company. We were especially interested in the relationship between formalization and employees' initiative to make changes in the company. Our companies were from following business area: Transport 3,7\%, Energetics 1,1\%, Finance 7,4 \%, Other 36,3\%, Commerce 19,5\%, Agriculture 2,1\%, Service 21,6\%, Education 2,1\%, Telecommunication 2,1\%, Tourism $1,1 \%$, Health service $3,2 \%$. Following table describes the companies by the number of employees, total number of managers and the span of control.

Table 2. Companies by the number of employees.

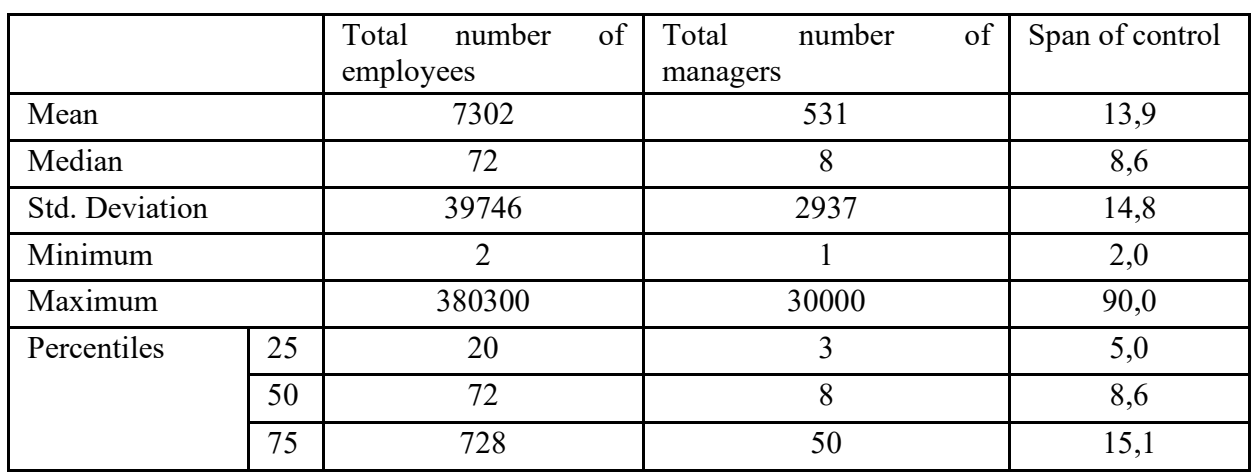

Source: Own processing.

Relating to the formalization we asked the managers about the degree of formalization in their organization. The results are seen in following table n. 3 .

Table 3. Degree of formalization in the company

\begin{tabular}{|l|l|l|}
\hline What is the degree of formalization in your company? & Frequency & Percent \\
\hline There are no formal rules, procedures, internal regulations. & 3 & 1,6 \\
\hline There are very few procedures, rules and internal regulations. & 33 & 17,4 \\
\hline Internal procedures, rules and regulations are present in each area. & 86 & 45,3 \\
\hline We have a large number of internal rules, regulations and procedures. & 30 & 15,8 \\
\hline $\begin{array}{l}\text { Internal rules, procedures and regulations exist for almost every } \\
\text { activity in the company. }\end{array}$ & 38 & 20 \\
\hline Total & 190 & $100 \%$ \\
\hline
\end{tabular}

Source: Own processing. 
Relating the changes we asked the managers if their subordinates are encouraged to submit improvement proposals, changes or innovations. The results are included in following table.

Table 4. Support employees to submit proposals for change.

\begin{tabular}{|l|l|l|}
\hline $\begin{array}{l}\text { Are your employees encouraged to submit improvement proposals / } \\
\text { changes / innovations? }\end{array}$ & Frequency & Percent \\
\hline Proposals for change are not desirable. & 6 & 3,2 \\
\hline It is not customary for us to submit proposals for change. & 51 & 26,8 \\
\hline Our superiors invite us to propose changes. & 89 & 46,8 \\
\hline We are strongly motivated to propose the change and innovation. & 44 & 23,2 \\
\hline Total & 190 & $100 \%$ \\
\hline
\end{tabular}

Source: Own processing.

Next question was aimed to the frequency the managers submit proposal for change or improvement. Our results are illustrated in table n. 5.

Table 5. Frequency of proposal to changer/improvement at work.

\begin{tabular}{|l|l|l|}
\hline $\begin{array}{l}\text { When did you made a proposal to change or improve at work for the } \\
\text { last time? }\end{array}$ & Frequency & Percent \\
\hline Lat week. & 44 & 23,2 \\
\hline Last month. & 68 & 35,8 \\
\hline Last six months. & 46 & 24,2 \\
\hline Last year. & 21 & 11,1 \\
\hline I haven't given any suggestion for over a year. & 11 & 5,8 \\
\hline Total & 190 & $100 \%$ \\
\hline
\end{tabular}

Source: Own processing.

Last questions relating the innovation and change was aimed to the time spent for innovation or change proposal creation. Our results are included in table 6 .

Table 6. Time for innovation or change proposal creation.

\begin{tabular}{|l|l|l|}
\hline $\begin{array}{l}\text { How much of your working time do you spend on innovation, } \\
\text { change, implementation of news? }\end{array}$ & Frequency & Percent \\
\hline I have no time for innovation. & 7 & 3,7 \\
\hline I have very little time for innovation and change. & 59 & 31,1 \\
\hline I have adequate scope for innovation and change. & 87 & 45,8 \\
\hline I spend a lot of my time working on changes. & 33 & 17,4 \\
\hline I spend most of my time on changes and innovative projects. & 4 & 2,1 \\
\hline Total & 190 & $100 \%$ \\
\hline
\end{tabular}

Source: Own processing

Based on these results we created following hypothesis to be tested :

H1: As formalization increases, the initiative to change decreases.

$\mathrm{H} 0$ : There is no statistically significant association between the formalization and the initiative to change.

We used regression of summary formalization and innovation variables. The significance level was $5 \%$. Our results are presented in following tables. 
Table 7. Parameter Estimates - Testing hypothese

\begin{tabular}{|l|l|l|l|l|ll|}
\hline \multicolumn{5}{|l|}{ Parameter Estimates } \\
\hline Dependent Variable: Innovations \\
\hline Parameter & $\mathrm{B}$ & Std. Error & $\mathrm{t}$ & $\mathrm{p}$ & $\begin{array}{l}\text { Partial } \\
\text { Squared }\end{array}$ & Eta \\
\hline Intercept &, 644 &, 026 & 24,595 &, 000 &, 763 & \\
\hline Formal &,- 166 &, 058 & $-2,855$ &, 005 &, 042 \\
\hline
\end{tabular}

Source: Own processing.

Table 8. Hypotheses testing - Tests of Between-Subjects Effects

\begin{tabular}{|l|l|l|l|l|l|}
\hline \multicolumn{5}{|l|}{ Tests of Between-Subjects Effects } \\
\hline Dependent Variable: Innovations \\
\hline Source & Type III Sum of Squares & df & Mean Square & F & p \\
\hline Corrected Model &, $279^{\text {a }}$ & 1 &, 279 & 8,151 &, 005 \\
\hline Intercept & 20,722 & 1 & 20,722 & 604,933 &, 000 \\
\hline Formal &, 279 & 1 &, 279 & 8,151 &, 005 \\
\hline Error & 6,440 & 188 &, 034 & & \\
\hline Total & 70,629 & 190 & & & \\
\hline Corrected Total & 6,719 & 189 & & & \\
\hline R Squared $=, 042$ (Adjusted R Squared $=, 036)$ & & & & \\
\hline
\end{tabular}

Source: Own processing.

The dependence of the degree of innovativeness on the degree of formalization is significant in the negative direction $(\mathrm{p}=0.005)$. Thus, the hypothesis $\mathrm{H} 1$ was confirmed.

\section{Discussion}

Hamel-Zanini [8] point out that bureaucratic structures are resistant to change. Bureaucracy destroys the value system of businesses in a myriad of ways, including slowing down problem resolution, discouraging innovation, and redirecting a great deal of time to internal policy making and "system functioning" solutions. The authors (Sherf Tangirala - Venkataramani, [7] prove that managers in bureaucratic enterprises themselves do not support innovation by their subordinates because they have to follow a system of formal rules and communicate every change with senior management. But if managers had real autonomy in decision making, they were up to 30 percent more likely to support innovation, ideas, and demand feedback from their subordinates. In his study, Cochran [17] also deals with bureaucracy and innovation. It argues that in promoting innovation, it is imperative to allow people to make mistakes, but this does not allow or eliminate bureaucracy through the introduction of a high level of formalization. Hamel [18] proved that the compromise between control and freedom is possible. In our research, we looked at the relationship of formalization and employee initiative to make changes. We have found that almost $36 \%$ of businesses report a high level of formalization, while reporting large or high levels of formalization. full coverage of its activities by internal procedures and formal documents. Almost $35 \%$ of managers confirmed that they have no time, respectively. very little time to propose amendments. In addition, up to 30 percent of all businesses reported that proposals for change are not desirable and it is not customary for us to submit 
proposals for change. Through regression analysis, we have shown that, as the level of formalization increases, the rate of innovation and change in the enterprise is decreasing. Therefore, we agree that excessive formalization as one of the pillars of bureaucracy is an obstruction in change and development in the enterprise.

\section{Conclusion}

Our contribution is dedicated to formalization and its impact on employee initiative to make changes in the organization. In a sample of 190 companies, we confirmed that with the increasing formalization, the initiative of employees to change has been decreasing. We have found that almost $36 \%$ of businesses report a high level of formalization. Almost $36 \%$ of companies confirmed full coverage of its activities by internal procedures and formal documents. Almost $35 \%$ of managers confirmed that they have no time, respectively very little time to propose any change or improvement. In addition, up to 30 percent of all businesses reported that proposals for change are not desirable and it is not customary for us to submit proposals for change. We can state that excessive formalization as one of the pillars of bureaucracy is an obstruction in change and development in the enterprise.

The research results published in the article are the results of the project of the grant scheme VEGA 1/0412/19 Human Resource Management Systems in the 4. Industry Era.

\section{References}

1. J. Váchal, M. Vochozka, Podnikové ř́izení (Praha: Grada, 2013)

2. M. Weber, M. Autorita, etika a společnost: pohled sociologa do dějin (Praha: Mladá fronta, 1997)

3. D. Organ, Ch. Greene, The Effects of Formalization on Professional Involvement: A Compensatory Process Approach. Administrative Science Quarterly 26, 2 (1981)

4. H. Mintzberg, Structure in Five: Designing Effective Organizations. (Englewood Cliffs NJ: Prentice Hall, 1983)

5. R. B. Armandi, W. Mills, W. Edgar jr., Bureaucratic and Personalized Strategies for Efficiency and Organization: An Investigation of Structures and Efficiency in a Set of 104 Profit-Seeking Firms, The American Journal of Economics and Sociology 44, 3 (1985)

6. R. Gulati, The Soul of a Start-Up. [online]. Harvard Business Review, July-August, 2019. [accessed: 2020-02-02]. Available at: https://hbr.org/2019/07/the-soul-of-a-startup

7. N. Sherf, E. Tangirala, S. Venkataramani. Research: Why Managers Ignore Employees' Ideas. Harvard Business Review, April, 2019. [accessed: 2020-02-02]. Available at: https://hbr.org/2019/04/research-why-managers-ignore-employees-ideas

8. G. Hamel, M. Zanini, The End of Bureaucracy. Harvard Business Review, NovemberDecember 2018. [accessed: 2020-02-02]. Available at: https://hbr.org/2018/11/the-endof-bureaucracy

9. M. Sedlák, Základy manažmentu. 2. preprac. a dopln. vyd. (Bratislava : Iura Edition, 2012)

10. P. G. Aquinas, Organization structure and design, applications\&challenges, (New Delhi, Excel Books, 2008) 
11. G. Hofstede, J. Hofstede, Kultury a organizace : software lidské mysli : spolupráce mezi kulturami a její důležitost pro prežití. (Praha : LINDE nakladatelství s.r.o., 2007)

12. L. Neščáková, L. Marelová Vnitřní závazné předpisy zaměstnavatele a jiné pracovněprávní úkony, (GRADA Publishing, a.s., 2013)

13. E. Basol, O. Dogerlioglu, Structural Determinants of Organizational Effectiveness Journal of Organizational Management Studies, (2014)

14. T. Juillerat, Friends, not foes?: Work Design and Formalization in the Modern Work Context. Journal of Organizational Behavior 31, (2010)

15. P. Neves, A. Lopez, M. Cunha, A High-Growth Firm Contingency Test of the Formalization-Performance Relationship. Journal of Small Business Management 57, (2019).

16. C.A. Belsito, C.R. Reutzel, SME employee performance appraisal formalization and trust in leadership change, International Journal Of Organizational Analysis 28, (2019)

17. T. Cochran, How I Led Change in the U.S. State Department Bureaucracy. Harvard Business Review. January 04, 2017. [accessed: 2020-02-02]. Available at: https://hbr.org/2017/01/how-i-led-change-in-the-u-s-state-department-bureaucracy

18. G. Hamel, General Management, First, Let's Fire all the Managers, Harvard Business Review, December 2011 [accessed: 2020-02-02]. Available at: https://hbr.org/2011/12/first-lets-fire-all-the-managers 